Published on Reviews in History (https://reviews.history.ac.uk)

\title{
INTERVIEW: The Politics of Race in Britain and South Africa
}

Review Number: 1858

Publish date: Thursday, 19 November, 2015

Author: Elizabeth Williams

ISBN: 9781780764207

Date of Publication: 2014

Price: $£ 62.00$

Pages: 288pp.

Publisher: I.B. Tauris

Publisher url: http://www.ibtauris.com/Books/Society\%20\%20social\%20sciences/Politics\%20\%20government/Inte D7DF-403F-A234-82FAE9B3F795\%7D

Place of Publication: London

Reviewer: Jordan Landes

In the latest of our occasional Reviews in History podcast series, Jordan Landes talks to Elizabeth Williams about her most recent book, the first to examine the British support for the anti-apartheid movement among its own black communities.

Elizabeth Williams is a subject librarian at Goldsmiths University of London.

Jordan Landes is subject librarian at Senate House Library, University of London.

You can listen to the interview here [2].

Source URL:https://reviews.history.ac.uk/review/1858

Links

[1] https://reviews.history.ac.uk/item/145031

[2] http://podcast.ulcc.ac.uk/accounts/SAScasts/ReviewsinHistory/LandesonWilliams.mp3 